\title{
The value dominant "Laicite" as part of the media picture of the world of France
}

\author{
Gulnar Abdikerimova - Kuliyash Duisekova - Zhanat Bissenbayeva
}

DOI: 10.18355/XL.2020.13.01.06

\begin{abstract}
In the multifaceted social life of modern France, the concept (phenomenon?) Of "secularism" - "Laicité" belongs among the most essential topics discussed today. It represents one of the fundamental values of the country, emphasized by the standards of multiculturalism in the era of integration in the information space while facing the changing nature of the national geopolitics of countries in the modern world. Besides the traditional "ideals of democracy" and "human rights," the so-called "Laicite" is in complex, sometimes conflicting relationships in between. If earlier the concept of "secularism" or "Laicité" was the subject of discussion and research primarily by historians and politicians, then the global processes described above have led to the fact that it goes beyond the scientific framework and receives broad resonance in the mass media as a relevant topic of public debate. The article identifies current axiological verbal accents that have changed dynamically more than once over a relatively short historical period, or, on the contrary, despite all the changes in the social system of values, ontologically unshakable spiritual and moral supports of man were found. The authors do this within the framework of the problem of representing "Secularism" in France's newspaper discourse, highlighting the facts of everyday life of French society through the media on this issue.
\end{abstract}

Key words: value, "Laicité," media, picture, world, France

\section{Introduction}

In France, the form of the cultural concept laïcité (secularism) has been gaining wide popularity, gaining its supporters from intellectual circles to political leadership and other segments of the society. Nevertheless, PRIVACY (LAICITE) is not atheism at all; and it is not religiosity. To a lesser extent, it is a unique religion. (Valco, 2018) Secularism is not aimed at God but at society. This is not a typical worldview but a civic organization of social, cultural and political life of the nation. Not a belief, but a principle, more precisely, a carefully organized set of principles.

However, the initial ideological/cultural concept of Laïcité was a modest legal concept. When, in 1905, the Third Republic proclaimed the separation of church and state, the government proposed a simple definition of secularism. The new law read "Laïcité (secularism) guarantees freedom of choice" to all French citizens.(Grieswelle, 1978) Subsequently, this law was developed in the constitution of the Fifth Republic (present-day France): Laïcité ("secularism") "guarantees the equality of all citizens before the law, regardless of their origin, race or membership in any religious doctrine." In principle, the vision of the concept of "secularity" by the architects of the 
French concept of Laïcité was not much different from the vision of the concept of "secularity" by the authors of the First Amendment of the US Constitution. As in the United States, secularism ("secularism") in France initially implied religious pluralism in the affairs of the state and the lives of its citizens. No more, no less.

In this research, we are analyzing a picture, or rather, a vision of the world represented by the French concept of Laïcité. However, first we need to discuss the picture of the world by itself. By 'Picture of the world' one usually means an image, or rather, a system of images, forming a specific idea of what we see around us, integrated into a meaning-conferring narrative. (Valco, 2018, p. 174) In spite of people's sharing a specific 'picture of the world,' the knowledge of each person is unique and individual because everyone understands the same things and phenomena in their own way. This often results in misunderstandings and conflicts among people. (Petkovsek, 2014) Tensions on individual level are mirrored on the tribal or national level. Individual nations are not alike, despite having much in common. What we have in common are called universals. However, if there are universals, then there must also be something unique.

Different nations also differ, each with its own view of the world, its own vision of the world. Language reflects a general idea of all the people speaking it, engaging, among other things, in conversations about how the world works. Language is a mirror that stands between humans and the world.

Each language reflects its own picture of the world of an individual human tribe/nation. In the words of each language, it reflects how the world was seen and understood. Therefore, for example, for some northern peoples, snow is one of the basic concepts of the world. Thus, in the language, there are word-names for falling snow; for snow from which you can build a needle, make blocks for a home, etc. For us, however, such detailed designations of snow are not needed. Moreover, the Africans do not have it at all - which means there is no word-name for this phenomenon.

The linguistic picture of the world differs from the actual reality of the world. In a particular language, there is an unspoken collective agreement of speakers (users of the language) to express their thoughts in a certain way. Therefore, the picture of the world of different peoples can be different as they categorize the same subject situations.

What is the difference between the concepts of "picture of the world" and "linguistic picture of the world", the language picture representing "the world in the mirror of language"? It is important to realize that the facts of language are not only a kind of code and a way of expressing thoughts but a reflection of the mentality of the people. The picture of the world is a reflection in the human mind of the surrounding world. Language accumulates the collective consciousness of an ethnos, including prescientific and, being an intermediary between a person and reality, captures a nation-specific vision of the world.

Modern culture has lost the status of literary-centered culture and shows all signs of media-centricity. Media around the world act as a dominant factor in shaping the worldview of the individual and the value 
orientation of society. Moreover, they are not only a translator of the already established cultural achievements of peoples, but they themselves are involved in the formation of new value-significant landmarks. The media offer their own picture of the world to the mass addressee, and today it dominates the entire space of human existence, at all levels of the social structure of society. (Pala, 2015) In this regard, not only the description becomes acutely relevant, but also the understanding of the media picture of the world from the point of view of its praxeological function.(Averina, 2010)

The picture of the world is a fundamental concept in the modern paradigm of humanitarian knowledge: it is studied in philosophy, sociology, psychology, in several philological disciplines (cognitive science, psycholinguistics, pragmatics, sociolinguistics, neuro-linguistics, etc.). Each of these sciences interprets the concept of a picture of the world in accordance with the dominant cognitive modes and, as a rule, focuses on those aspects of the picture of the world that correspond to the modeling method developed based on its categorical apparatus. (Arnold, 1991)

In the course of the study, the following scientific hypothesis was put forward: modern Russian culture has lost its literature-centrism and moved into the category of media-centric cultures in which the language of the media, communication, and propaganda defines the culturally specific features of the society in which these media operate. The media and communications synthesize in themselves the primary, fundamental features of Culture and Civilization as two aspects of a person's creative activity.(Barthes, 1970)

On the one hand, they, by their deep essence, are products of human civilization and technical activity of a person, on the other hand, they operate on the main product of a person's national and cultural creativity - language. And it is precisely the language that represents the essential characteristic in the activities of the media in the formation of media pictures of the world in the minds of the mass addressee. Using the existing arsenal of culture and interpreting it using various discursive strategies, they construct their own world, different from the real world, and offer it as the only possible mass destination.

Since the humanities study both the real object of reality and its mental-discursive reflection as a text (in the broad sense of the word) not by themselves, but through their ideal constructions (models), it can be assumed that the media discourse and media picture of the world lend themselves to modeling in the framework of the paradigm of a particular humanity. Since the media discourse belongs to the persuasive-perlocutionary type of discourse, we can talk about the initial rhetoric of his texts, and therefore about the possibility of their analysis using categories of rhetoric and, therefore, building a model of media discourse and media picture of the world. Moreover, since rhetoric, unlike other philological disciplines, includes the axiological aspect as one of the dominants, it can not only describe and model the structure of this discourse but also evaluate the

XLinguae, Volume 13 Issue 1, January 2020, ISSN 1337-8384, ISSN 2453-711X 
discursive interpretive activity that is carried out by the media.(Gallardo, 1994)

However, classical rhetoric offers a paradigm of technical means for creating these texts by the addressee, and the rhetoric of the second half of the 20th century has updated its terminological thesaurus with new disciplines (pragmatics, cognitive science, psycho-and sociolinguistics) that it is not always possible to see a tradition in the research of non-sense.

In this work, we propose a new categorical scientific apparatus for describing a media discourse based on the traditional concepts of ethos, logo, and pathos and enriching them with the research of various schools of rhetoric. With the help of updated terminology, it became possible not only to describe the media discourse but also to reveal the neorhetorical model of this discourse, through which the world's media picture itself is formed.

As is generally known, "the picture of the world, with all its complexity, time and social ambiguity, each nation has its own through lines, enshrined in the vocabulary, grammar, syntax of the language" ( Hodge, 1993). Therefore, it is worth noting that the first who tried to understand the character traits of what constitutes a typical 'French person' were French writers, who gave him the definition of "a person without qualities" or deduced his character from a feeling of devotion to his country and his monarch.

The language and culture of the people comprising a nation is always inextricably linked. Language units and their meanings form and reflect the specificity of national pictures of the world. In the study of this specificity, unique methods of linguistic-cultural analysis played a significant role presented in the works of Yu. D. Apresyan, E. Benvenista, L. Vaisgerber, A. Vezhbitskaya, B. M. Gasparov, V. von Humboldt, M. A. Krongauz, E. S. Kubryakova, J. Lionza, J. Lakoff, V. A. Maslova, A. A. Potebni, E. Sepira, F. de Saussure, S. G. Ter-Minasova, B. Warfa, R. I Jacobson.

A cultural concept, in conjunction with its linguistic expression, is a unit of linguistic culture. Groups of cultural concepts, united by a semiotic field, make up the conceptual sphere. S. A. Askoldov-Alekseev, S. G. Vorkachev, V. G. Zusman, V. I. Karasik, N. A. Krasavsky, D. S. Likhachev, Z. D. Popova and I wrote about concepts and the concept sphere. A. Sternin, Yu. E. Prokhorov, G. G. Slyshkin, Yu. S. Stepanov.

The cultural and philosophical aspects of understanding the concept and conceptuality were facilitated by the work of Yu. A. Asoyan, M. M. Bakhtin, L. Wittgenstein, K. Gierz, P. Kampitts, L. P. Karsavin, V. M. Mezhuev, S. S. Neretina, A. A. Pelipenko, G. Rickert, M. Heidegger, J. Heyzingi, M. M. Shibaeva, G. G. Shpet, M. B. Yampolsky.

Among the other factors, the formation of the cultural picture of the world is significantly influenced by the concepts that make up the national conceptual sphere, reflecting in its essence the uniqueness of natural conditions, linguistic characteristics, the history of the country, etc. and consolidating all this in its composition. The complexity of the conceptual content of concepts can influence the formation of the cultural picture of the 
world in its most diverse aspects, changing them both positively and negatively.

Some of the nuances of the manifestations of such an impact can be fully understood only by speakers of specific languages and cultures. Others contribute to the universalization and creation of an attractive image of national culture. Thus, we can say that the perception of culture as its bearers and representatives of other cultures is always dependent on the state of the national conceptual sphere as a factor in the formation of the cultural picture of the world.

The phenomenon called the "picture of the world" is as ancient as the person himself. The primary creation of world pictures for a person corresponds in time to the process of anthropogenesis. However, the reality, which is called the term "picture of the world," only recently began to be considered the subject of scientific and philosophical analysis. The problem of world pictures is vast, like any problem field affecting global issues, among which are people in the context of culture, nature and culture, culture and history, sacred and secular, etc. (Lausberg, 1973)

One way or another, the focus of attention is man's place in the world, his attitude to the world around him and his permanent creation of this world. The vastness of this topic is a special kind. Not only because the pictures of the world are endless and changeable, but also because they are the result of human activity. The cultural picture of the world is a space that is continuously growing, turning into a noosphere. Studying the problems associated with it is already a process of its growth.(Labov, 1972)

The term "cultural picture of the world" in recent years has become very common and even fashionable. If earlier it was customary to write about something "in the context of culture," now you can increasingly see the phrase "in the space of the cultural picture of the world" or simply "in the cultural picture of the world," which, however, seems to be more productive and undoubtedly, is a consequence of increased attention to this concept in today's research. In modern science, there is a complication of the concept of a picture of the world. As a result, it appears as a whole, capable of reproducing complex, interpenetrating spatio-temporal structures that have rich semantics. ( Mann, 2001)

Let us turn to the problem of the historical typology of world pictures. Already in the philosophical theories of the Ancient world, one can notice the prerequisites for the emergence of the concept of a picture of the world. All of them (scientific, philosophical, mythological, religious, artistic, linguistic, cultural pictures of the world), one way or another, are systematically interconnected and, thus, can be compared with each other. According to physicist M. Planck: "Even in ancient times, when the study of nature began, there was an ideal, a high task: to combine the variegated variety of physical phenomena into a single system"(Scott, 1998).

He notes two stages in the formation of a picture of the world. Planck considers the first stage a sensual, direct perception of reality, leading to the creation of a "pre-scientific picture of the world" (Perelman, 1952). It bears a cultural specificity and is filled with special content for each nation 
and, along with the linguistic one, becomes the foundation in the formation of the cultural picture of the world. Bringing the "motley subjective diversity" in order with the help of universal scientific laws, he notes as the second stage. Thus, what we consider a 'scientific picture' of the world is formed.

\section{Methods}

The choice of research methodology is due to its interdisciplinary nature and linguo-philosophical systematic approach to the understanding of the media picture of the world. The work combines a linguistic and philosophical view of the text in general and the media text in particular. In this regard, the methods developed both in the philological sciences proper and in philosophy, psychology, sociology, etc. were used.

The nomothetic method aimed at identifying the general laws of the object and subject of study became the basic method of the research. This method is directly related to the interpretation problem. Therefore, a wide range of interpretation methods was used in the research: general stylistic analysis, analysis of text and text structures, discourse analysis method, cognitive-pragmatic analysis method, semantic and semiotic analysis method.

We used the leading traditional methods of scientific research, which include abstraction, generalization, analysis, synthesis, analogy, typologization, etc. Functional-stylistic, contextual-situational, and cultural studies methods were also used. In terms of understanding the essence of the concept, corresponding to the interdisciplinary nature of the study, the basic concept of the concept was taken as the main cultural unit in the mental world of a person, in which, on the one hand, the concept is laid down, and on the other, everything that makes it a fact culture - etymology, a brief history of this concept, modern associations, assessments, experiences. The role of experiential learning, in this regard, needs to be further explored. (Glavica, 2019)

The following research methods were used in the research: methods of synchronous and diachronous analysis and typology of cultural texts used in cultural studies, historical-genetic, structural-semiotic, structuralfunctional, comparative, content analysis, as well as methods of linguoculturology:

- a method of continuous sampling of empirical material,

- method of conceptual analysis,

- distribution analysis method,

- method of comparative analysis,

- method of contextual analysis.

The empirical basis consisted of publications from French newspapers and magazines and literary texts of French classical literature. Using a continuous sampling of texts from the newspapers and the magazines, we investigated the functioning of French concepts. These concepts are regularly found in publications of the French media and are presented both in the form of synonyms and allusions, and the word-concept itself. 
The scientific novelty of the research is that the national conceptual sphere, studied mainly in the aspect of language and, accordingly, linguistic approaches, is considered from the point of view of cultural studies as a factor in the formation of the cultural picture of the world. Concepts are studied in the "border zone" of cultural contexts, which gives the research additional scientific novelty.

The contents and results of the study may be summarized followingly:

- the paramount importance of the national conceptosphere, playing a structure-forming role in shaping the cultural picture of the world, has been identified, while the local specificity of national concepts plays a vital role in shaping the image of culture;

- the study analyzed the structure and cultural functions of the concept as a multidimensional system, characterized by a large number of nuances and flexible dynamics, which makes the culture-forming factor unique in each individual case;

- a multilevel analysis of the components of the national conceptual sphere has revealed that its important elements are geopolitical, historical, ethnopsychological concepts and that their complex structural relationship models the image of culture in its national aspect;

- our study has revealed that in those cases when a system-forming, important and multifunctional concept of culture was chosen for analysis, it should be continuously repeated, considered and interpreted in various systems of culture and art: politics, painting, music, etc. using adequate to the subject methods and criteria of modern cultural studies;

- using the chosen integrated methodological approach, the key elements of the French national conceptosphere and their determining factors, forming the cultural picture of the world, were investigated.

The role, functions and historical dynamics of French concepts are examined in detail through the prism of classical French media and materials of the modern press.

\section{Discussion}

The cultural picture of the world has been and remains one of the most interesting and relevant objects of research in modern science. Today, an increase in interest in it is mainly due to the awareness of the role that the pictures of the world play in the processes of globalization and sociocultural dynamics in general. The emergence, growth, resolution of cultural contradictions - this is what is today a problematic field for the activities of specialists related to cultural sciences.

The formation of world pictures always takes place based on the national conceptosphere, which has developed during the historical process on the basis and under the interaction of several factors. Consideration of these factors, specific concepts and the conceptosphere of peoples and nations as a whole helps to identify many universal and specific features of culture and thereby often avoid and/or prevent many problems associated 
with misunderstanding, tensions, and differences in worldview. (Slivka Kardis, 2018) The conceptualization of the picture of the world in cultural studies is based on the search and analysis of key concepts that concentrate, accumulate and translate the underlying meanings of one or another nationally, historically and socially determined cultural continuum and constitute the national conceptual sphere.

Within the European cultural space, we can distinguish many longstanding unresolved contradictions that gradually influence its sociocultural dynamics. Studies of the formation of a cultural picture of the world with the help of an analysis of the conceptual sphere can help penetrate the depths of these processes and better understand the culture as a whole.

The specificity of the media is primarily in their synergistic combination of two dichotomously interconnected vectors of the movement of human activity to create "cultural" and "civilizational" values. The peculiarity of the media should be recognized that they, being a product of Civilization, do not fit into the traditional idea of civilizational activity: the emergence of new and more advanced ways of transmitting information does not cancel the old channels of communication. Services in Civilizations occur in them with the help and through the main product and carrier of Culture the national language.

Modern media are not only repeaters of the values that have already been established and have long existed in society but also form a new valueparadigm in the minds of the mass addressee. This suggests that such media activities should be considered as activities to construct a picture of the world, which we call the media picture of the world. The specificity of this picture of the world lies in the fact that it not only transforms and deforms the familiar world image of native speakers of the Russian language but also constructs through this language a quasi-realistic picture of the world in which actual reality is replaced by the reality of media discourse and offered to the mass addressee as the only possible and only true.

Since the modern media picture of the world shows all the signs of discreteness, discontinuity, and mosaic, it requires understanding not from the point of view of analysis of its individual components (fragments), but from the point of view of its relation to the Whole as an ontological sign of human being in the world. Modern humanitarian knowledge, and in particular philology, is gradually moving away from both excessive segmented and the immanence of the existing paradigms of the linguistic approach in describing the object of study, and from the desire of a particular approach in language learning to dominate. In line with the trends of the XX century, philological branches of knowledge are combined and synthesized with other humanities sociology, psychology, philosophy, etc. In this context of interdisciplinarity, revived and updated rhetoric has come to the forefront of humanitarian knowledge today.

An analysis of the elements of the national conceptual sphere makes it possible to clarify the specifics and understand the objective inconsistency of the cultural picture of the world, national values, national character, and self-awareness. The complex structural relationship of geopolitical, historical, 
ethnopsychological concepts models the image of culture in its national aspect.

The concept is a multidimensional education that contains not only conceptual-definitional but also associative, evaluative, connotative and figurative characteristics that should be taken into account when describing it. The functioning of the concept in the cultural system is largely determined by the specifics of local nuances and flexible dynamics, which makes it unique as a culture-forming factor in each individual case. Moreover, the methodology for describing a concept will always depend on the type of concept.

Concepts enshrined in the sphere of language and cultural images are a unique means of expressing thoughts and objectivizing all structures of consciousness. It follows that in those cases when a system-forming, important and multifunctional concept of culture is chosen for the analysis of the world picture, it must be considered and interpreted in various systems of culture and art using methods and criteria adequate to the subject modern cultural science.

\section{Conclusion}

The theoretical significance of the research lies in the fact that it lays the foundation for a holistic concept of media as a new type of private rhetoric of the language of the media. The study corrects, refines and updates the categorical-terminological apparatus and includes it in a single context of media sciences. The concept proposed in the work contains the potential for further detailed development of its main provisions and for expanding the boundaries of the methodology in understanding not only the media discourse and media picture of the world but also any type of discourse, any type of picture of the world. The results of the work can be used in related disciplines and scientific fields: pragmatics (pragmalinguistics), cognitive science, linguistics, speech culture, in text theory, in the theory of journalistic creativity, etc. It is also essential that this study expands the field of application of methodology in the humanities.

The next theoretical significance of the work is to clarify and comprehensively develop the concepts of the national conceptosphere in relation to a particular country and its existing cultural picture of the world. The research contributes to cultural studies and linguistics, as well as cultural studies of the national specifics (specific cultural concepts), and also to the study of structural elements and segments of the conceptosphere of French culture. The analysis of the structure and semantics of French cultural concepts, compromise, and music, can be a contribution to the development of a methodology for the culturological study of concepts and features of the national conceptosphere.

The practical significance of the study is seen in the fact that the work and its conclusions will contribute to education, and above all, higher education. The approach proposed in the work allows us to expand the concept of interdisciplinarity and fit the model of education into a new anthropocentric paradigm formed by modern higher education. It seems 
promising to create special courses "Media rhetoric" at the faculties and departments of journalism. It is possible to include the results of the research in sections of lecture courses on the following linguistic disciplines: stylistics, history, and theory of rhetoric, media-linguistics, history of linguistic teachings, cultural studies, and linguoculturology, pragmalinguistics, in the theory of journalistic creativity. The main provisions of the research will be of interest for special courses of a philosophical sense, in which the communicative aspects of culture as a whole are studied.

The other practical significance of the study lies in the possibility of using its results in the teaching of cultural studies, linguistic and regional studies, as well as in the application of the materials and conclusions of this work in further studies of the national conceptosphere in general and the French cultural world in particular.

\section{Bibliographic references}

AVERINA, A. V. 2010. Epistemic modality as a linguistic phenomenon (based on German material). In: KRASAND, Moscow, URSS Publ., 190 p.

ARNOLD, I. V. 1991. Fundamentals of scientific research in linguistics [Text]: tutorial / I.V. Arnold. - M.: Higher school, 140 p.

GLAVICA, I.N. 2019. The Role of Experiential Learning in the Gestalt Pedagogical Model of Teaching and Learning by Albert Hofer. In: Bogoslovni Vestnik, vol. 79, n. 1, pp. 191-202.

RICOEUR, P. 1995. Conflict of Interpretation. Essays on Hermeneutics / Per. I. Sergeeva. In: Moscow Philosophical Fund. Academia Center; MEDIUM, 415 p.

ROGOZINA IV. 2003. Media picture of the world: cognitive-semiotic aspect: dis. . Doct. filol. Sciences: Barnaul, $430 \mathrm{p}$.

ADORNO THEODOR, W. 2011. Televisione come ideología. MicroMega. almanacco di filosofía. n. 5, pp. 159 - 174.

ADORNO THEODOR, W. 2011. Leadership democratic e manipolazione delle masse MicroMega: almanacco di filosofía. n. 5, pp. 181 - 193.

ARONSON, E. - TURNER, J. - CARLSMITH, J. M. 1963. Communicaition credibility and communication discrepancy as determinantsof opinion change. Journal of Abnormal and Sotial Psichology. n 67.

BARTHES, R. 1970. L'ancienne rhétorique. Aide-mémoire. Communications. n. 16, pp. 172 - 229.

CHAIKA, E. 1989. Language: The social mirror. Cambridge. Newbury. 374 p.

FOWLER, R. 1991. Language in the news: Discourse a. ideology in the press. In: N.Y . Routledge, $254 \mathrm{p}$.

GALlARDO, M. A. 1994. La musa de la Retórika. Problemas y métados de la ciencia de la literature. Madrid: Conaejio Superior de Investigaciones Cientificas,

GRIESWELLE, D. 1978. Rhetorik und Politik: Kulturwissenschaftliche Studien. München In: Minerva, $155 \mathrm{p}$.

HODGE, R. - KRESS, G. 1993. Language as ideology. N.Y .In: Routledge, 230 p.

LAUSBERG, H. 1973. Hangbuch der literaturischen Rhetorik. 2. Aufl.-Munchen, Bd.1.

LABOV, W. 1972. Sociolinguistic patterns. Philadelphia In: Univ. of Pennsylvania press, $344 \mathrm{p}$.

PALA, G. 2015. The family in media ciphers. In: European Journal of Science and Theology, vol. 11, n. 6, pp. 45-56.

MANN, W. C. - THOMPSON, S.A. Structure Theory: Toward a Functional Theory of Text Organization. pp. 243-281. 
PERELMAN, C. - OLBRECHT-TYTECA, L. 1952. Rhétorique et philosophie. In: PUF

PETKOVSEK, R. 2014. Nasilje in etika kriza v luci eksistencialne analitike in mimeticne teorije. In: Bogoslovni vestnik, vol. 74, n. 4, pp. 575-592.

SCOTT, A. F. 1980. Current Literary Terms: A Concise Dictionary of the Origin and Use. London.

SLIVKA, D. - KARDIS, K. 2018. Examining the Interplay of Church and Family in Cultivating the Faith in Teenagers: Towards a New Strategy. In: European Journal of Science and Theology, vol. 14, n. 3, pp. 53-62.

TODOROV, T. Littérature et signification. In: Langue française,, 1969. La stylistique, sous la direction de Michel Arrivé et Jean-Claude Chevalier. pp. 115-116.

VALCO, M. 2018. Sekularizacia ako vyzva pre tradicne nabozenstva Europy podsa Charlesa Taylora [Secularization as a Challenge for Traditional Religions in Europe according to Charles Taylor]. In: Historia Ecclesiastica, vol. 9, n. 1, pp. 173-190.

Words: 5051

Characters: 32543 (18,08 standard pages)

Gulnar Abdikerimova

Abylai Khan Kazakh University of International Relations and World Languages

Almaty

Republic of Kazakhstan

prof. Kuliyash Duisekova

L.N. Gumilev Eurasian National University

Nur-Sultan

Republic of Kazakhstan

Zhanat Bissenbayeva

Al Farabi KAZNU

Almaty

Republic of Kazakhstan 